\title{
Synthesis of some new Acid hydrazones and their activity against Mycobacterium
}

\author{
Srivsatava Ritu*1, Pandeya S.N. ${ }^{2}$, Singh A.K. ${ }^{1}$, Anantham Sam ${ }^{3}$ \\ ${ }^{1}$ Harish Chandra P.G. College, Varanasi 221001, India, sriritu11@gmail.com \\ ${ }^{2}$ Saroj Institute of Technology \& Management, Ahimamau, Lucknow-226001, India \\ ${ }^{3}$ TAAFF 2000, Ninth Avenue south, P.O.Box55305, Birmingham Alabama U.S.A
}

\begin{abstract}
Twelve aryl acetic acid hydrazones were synthesized and tested first time for their antimicrobial activity. The structures of all these compounds were confirmed with the help of IR, ${ }^{1} \mathrm{HNMR}$, Mass spectra along with elemental analysis. Some of the target compounds show moderate activity against $\mathrm{H}_{37} \mathrm{RV}$ strain of Mycobacterium tuberculosis at a concentration of $10 \mu \mathrm{M}$.
\end{abstract}

Keywords- Aryl hydrazones, antimicrobial activity

\section{Introduction}

The global pandemic explosion of tuberculosis has resulted in death of thousands of people world wide (1.7 billion people)[1]. The treatment for tuberculosis involves among the other things is; isonicotinic acid hydrazides (isoniazide). The basic problem behind the treatment of tuberculosis is multi drug resistance(MDR) developed by the existing drugs like isoniazide, ethionamide, pyrazinamide, rifampicin. Therefore there is an urgent need for discovery of new drugs to control this disease. World wide various heterocyclic compounds and their derivatives like quinoxiline have shown antitubercular activity. Some heterocyclic thiourea derivatives are also known to exhibit antitubercular activity [2]. Benzoxazole thioureas are active against Microbacterium tuberculosis [3]. The antimicrobial activity of some derivatives of (7Hydroxy-2-oxo-2H-chromen-4yl)-acetic acid hydrazide has been reported recently [4]. In the present manuscript a series of substituted phenyl hydrazones containing various constituents were synthesized and tested for their antimicrobial activity. All the newly synthesized compounds characterized with the help of elemental analysis along with IR, NMR and Mass spectral analysis. The occurrence of hydrazine pharmacophore in these compounds is expected for high antimicrobacterial activity.

\section{Experimental}

Syntheses of these new compounds generally follow the following scheme I and II

Scheme-I

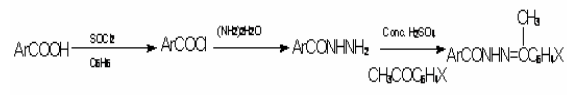

$$
\begin{aligned}
& \operatorname{ArNHNH} 2 \frac{\mathrm{CH} 3 \mathrm{COC} \mathrm{H}_{2} \times}{\mathrm{ArCONHN}}=\mathrm{C}-\mathrm{CH} \\
& \text { Scheme-II }
\end{aligned}
$$

The general procedure for the synthesis of compounds RSP 1 to RSP 12 is as follows

\section{Preparation of Hydrazides}

The pure Thionylchloride (15-20ml) was added to a solution of aryl acid in benzene and reflux it on a water bath for 20-30 minutes. After refluxing the reaction mixture was cooled followed by addition of $2-3 \mathrm{ml}$ of hydrazine hydrate. $2-3 \mathrm{ml}$ of hydrazine hydrate was added in the reaction mixture and re reflux the reaction mixture for 30 minutes. After 30 minutes methanol was added. The solvent was distilled off and the product was dried. Now distilled off the solvent and the product was vaccum dried. The synthesized compound was recrystallized using ethanol which afforded respective hydrazides.

\section{Preparation of Hydrazones}

Scheme I: The hydrazones were synthesized by adding equimolar quantity ( $0.1 \mathrm{~mole})$ of hot solution of respective hydrazides in dilute acetic acid or methanol to a solution of aromatic ketones in methanol. The reaction mixture was then refluxed for about 90 minutes; followed by addition of $1 \mathrm{ml}$ of concentrated sulphuric acid. The reaction mixture was then poured into crushed ice, followed by filtration and the product was recrystallized using ethanol which gives respective hydrazones.

Scheme II: The hydrazones were also synthesized by adding equimolar quantity ( $0.1 \mathrm{~mole})$ of hot solution of aromatic hydrazine in water to a solution of aromatic ketones ( $0.1 \mathrm{~mole})$ in methanol. The reaction mixture was then refluxed for about 90 minutes followed by addition of $1 \mathrm{ml}$ of concentrated sulphuric acid. The reaction mixture was then poured into crushed ice, followed by filtration and the product was recrystallized using ethanol to afford respective hydrazones.

\section{Result and Discussion}

The newly synthesized compounds were vacuum dried before characterization. The melting points of the synthesized compound were determined by open capillaries method. The homogeneity of the synthesized was routinely checked on running silica gel TLC plates using iodine as 
visualizing agent. All these compounds were characterized by elemental analysis by carloEbra1108 elemental analyzer. The result indicates that there is not much difference between observed and calculated values. The infra red spectra of the compounds were recorded on JASCOFTG-IR -5300 spectro photometer and the spectra shows proximal values which confirm the desired structure of the compounds. The ${ }^{1}$ HNMR spectra of the synthesized compounds were taken on JEOLFX90QFT spectrometer; using TMS as internal standard. The results of ${ }^{1} \mathrm{HNMR}$ spectra exhibit the appropriate values of peaks confirming the structure of compounds.

Table 1- Antimicrobial activity of aryl hydrazones

\begin{tabular}{|c|c|c|c|c|c|}
\hline \multirow{2}{*}{$\begin{array}{l}\text { Compo } \\
\text { unds }\end{array}$} & \multicolumn{2}{|c|}{ Substituents } & \multirow{2}{*}{$\begin{array}{l}\begin{array}{l}\text { Assay } \\
\text { MABA }\end{array} \\
\mathrm{IC50}(\mu \mathrm{g} \\
/ \mathrm{ml})\end{array}$} & \multirow{2}{*}{$\begin{array}{l}\mathrm{H}_{37} \mathrm{RV} \\
\mathrm{IC} 90(\mu \mathrm{g} / \\
\mathrm{ml})\end{array}$} & \\
\hline & $\mathrm{Ar}$ & $\mathbf{X}$ & & & \\
\hline \multicolumn{6}{|c|}{ Scheme I } \\
\hline RSP 1 & $\mathrm{C}_{6} \mathrm{H}_{5}$ & $4-\mathrm{OH}$ & 7100 & 7100 & Inactive \\
\hline RSP 2 & $\mathrm{C}_{6} \mathrm{H}_{5}$ & 4- $\mathrm{NH}_{2}$ & 7100 & 7100 & Inactive \\
\hline RSP 3 & $\mathrm{C}_{6} \mathrm{H}_{5}$ & $\mathrm{H}$ & & & \\
\hline RSP 7 & $\mathrm{C}_{6} \mathrm{H}_{5} \mathrm{CH}_{2}$ & 4- $\mathrm{NH}_{2}$ & 77.993 & 7100 & \\
\hline RSP 8 & $\mathrm{C}_{6} \mathrm{H}_{5} \mathrm{CH}_{2}$ & $4-\mathrm{OH}$ & & & \\
\hline RSP 9 & $\mathrm{C}_{6} \mathrm{H}_{5} \mathrm{CH}_{2}$ & $\mathrm{H}$ & & & \\
\hline RSP 10 & $\mathrm{Cl}-\mathrm{CH}_{2}$ & 4- $\mathrm{NH}_{2}$ & 80.945 & 7100 & \\
\hline RSP 11 & $\mathrm{Cl}-\mathrm{CH}_{2}$ & $\mathrm{H}$ & 46.377 & 7100 & \\
\hline RSP 12 & $\mathrm{Cl}-\mathrm{CH}_{2}$ & $4-\mathrm{OH}$ & 11.55 & 13.095 & \\
\hline \multicolumn{6}{|c|}{ Scheme II } \\
\hline RSP 4 & $\mathrm{C}_{6} \mathrm{H}_{5}$ & $4 \mathrm{NH}_{2}$ & 7100 & 7100 & Inactive \\
\hline RSP 5 & $\mathrm{C}_{6} \mathrm{H}_{5}$ & $\mathrm{H}$ & 77.32 & 7100 & \\
\hline RSP 6 & $\mathrm{C}_{6} \mathrm{H}_{5}$ & $4-\mathrm{OH}$ & 11.791 & 20.001 & \\
\hline
\end{tabular}

Acknowledgement

The authors are highly thankful to the TAAF Birmingham U.S.A. for antimicrobial activity against the bacterial strain.

\section{References}

[1] Pandeya S.N. (2009) Medicinal Chemistry \& Drug Design, S.G. Publishers, Varanasi, 322-328.

[2] Carta A., Loriga M., Paglietti G., Mattana A., Fioro P.L., Mollicotti P., Sechi L., Zametti S. (2004) Eur. J. Med. Chem., 39,195.

[3] Jaso A., Zarranaz B., Aldana I., Monge A. (2005) J. Med. Chem., 48, 2019.

[4] Cacie M., Trkovmi K., Cacie F., Has-Sckon E. (2006) Molécules, 11,134-147. 